\section{Cancer immunoediting and dioxin-activating aryl hydrocarbon receptor: a missing link in the shift toward tumor immunoescape?}

\author{
Ruggero Ridolfi, Massimo Guidoboni, \\ Laura Ridolfi \\ Immunotherapy Unit, Istituto Scientifico \\ Romagnolo per lo Studio e la Cura dei \\ Tumori (I.R.S.T.), Meldola (FC), Italy
}

\section{Abstract}

The aryl hydrocarbon receptor (AhR), a member of the PAS protein family, is found in organisms as diverse as Drosophila melanogaster, nematodes, and mammals. While several reviews have reported that AhR, once activated by agonist ligands, causes long-term effects such as modification of cell growth through cell cycle control, there is also recent evidence of its decisive role in immunosuppression. The most widely studied AhR agonist is 2,3,7,8-tetrachlorodibenzo-p-dioxin, which binds AhR with the highest known affinity, leading to profound suppression of both humoral and cellular immune responses, with praecox thymus involution, consequent thymocyte loss, and induction of T-cell apoptosis. Dioxin-AhR binding causes a decline in the number of dendritic cells and enhances apoptosis following their inappropriate activation. Dioxin-mediated activation of AhR also has a direct influence on the expansion of regulatory T-cells $\mathrm{CD}^{+}{ }^{+} \mathrm{CD} 25^{+} \mathrm{FoxP}^{+}$(T-regs) and an adverse affect on $\mathrm{CD}^{+}$T-cell responses. Dioxin released from industrial and waste incinerators over the last few decades has caused widespread contamination of food, leading to its accumulation in fatty tissue in animals and humans. The elimination half-life of dioxin in humans (7-10 years) may favor the potentially continuous and long-lasting activation of AhR, leading to perpetual immune suppression and facilitating the onset, growth, and diffusion of tumors, especially in young people. In the cancer immunoediting hypothesis, which subdivides the relationship between tumor and immune system into three phases: elimination, equilibrium, and escape, it is thought that dioxin accumulation may cause an inevitable shift toward tumor escape.

\section{Immune system and cancer}

The relationship between the immune system and malignant tumors undoubtedly is a complex one. ${ }^{1}$ At the end of the 1980 s, evidence was found of the ability of the host's immune system to recognize and selectively destroy cancer cells in opportune conditions in vitro. ${ }^{2}$ Over the following years, an increasing number of tumor antigens recognized specifically by the host's T-lymphocytes were identified. ${ }^{3}$ Such experimental evidence of the capacity of the immune system to discriminate between self and non-self forms the basis of the recognition and elimination of emerging tumors, in accordance with the theory of immunosurveillance. This key ability to distinguish between self and non-self is essential for an adequate response to external pathogens and growing tumor cells. ${ }^{4}$ Conversely, a state of immunodeficency can predispose to tumor development, and established tumors often generate immunosuppressive microenvironments that block productive antitumor immunity, thus establishing a vicious circle.$^{5,6}$ Basic research has clarified some of the mechanisms underlying spontaneous antitumor immunity and has formed the basis for the "cancer immunoediting" hypothesis, which divides the tumor immune response into three phases: elimination, equilibrium, and escape., ${ }^{7,8}$

The elimination phase occurs early during tumor growth, when productive antitumor immunity involving the production of interferon-gamma (IFN- $\gamma$ ) and the generation of tumor reactive cytotoxic T-cells is capable of efficiently eradicating malignant cells. ${ }^{9}$ During the equilibrium phase, however, the tumor becomes firmly established and the immune system can only inhibit progression. Although these tumors may remain stable for months or even years in the absence of therapy, transient suppression of an adaptive immune system can induce rapid tumor growth, indicating that these stable tumors were held in check by adaptive immunity. ${ }^{10}$ Following the equilibrium phase, tumors evolve to escape the immune response, enabling progressive tumor growth that becomes evident clinically. ${ }^{11-13}$

\section{Mechanisms of tumor immune escape}

Both innate and adaptive immunity are involved in the tumor antigen-specific immune response. ${ }^{14}$ Immune cells present in the tumor include those that mediate adaptive immunity, T-lymphocytes, dendritic cells (DCs), occasional B-cells, and also effectors of innate immunity; for example, macrophages, polymorphonuclear leukocytes, and rare natural killer (NK) cells..$^{15-17}$ Recent findings would seem to suggest that innate immunity plays a part in early immunosurveillance when a tumor is developing, whereas adaptive immunity intervenes to eradicate a tumor that already
Correspondence: Ruggero Ridolfi, Immunotherapy Unit, Istituto Scientifico Romagnolo per lo Studio e la Cura dei Tumori (I.R.S.T.), Via Maroncelli 40, 47014 Meldola (FC), Italy. E-mail: r.ridolfi@irst.emr.it or ruggero.ridolfi@virgilio.it

Key words: dioxin, cancer immunoediting, tumor immunoescape, aryl hydrocarbon receptor (AhR), T-reg lymphocytes.

Contributions: RR, study concept and design, and critical revision of the manuscript for important intellectual content; LR, MG, acquisition of data; RR, LR, MG, analysis and interpretation of data, and drafting of the manuscript. The study was approved by all authors.

Acknowledgements: the authors wish to thank Gráinne Tierney for editing the manuscript.

Conflict of interest: the authors report no conflicts of interest.

Received for publication: 25 February 2010. Revision received: 4 May 2010.

Accepted for publication: 6 May 2010.

This work is licensed under a Creative Commons Attribution 3.0 License (by-nc 3.0).

CC Copyright R. Ridolfi et al., 2010

Licensee PAGEPress, Italy

Journal of Nucleic Acids Investigation 2010; 1:e6 doi:10.4081/jnai.2010.e6

exists, albeit at an initial stage. ${ }^{4,15}$

The tumor microenvironment is a substrate in which a condition of progressively increasing immunosuppression occurs. ${ }^{18-20}$ It controls and is controlled by regulatory myeloid and lymphoid cells and immune suppressive factors released by the tumor itself. ${ }^{21,22}$ A large number of tumor infiltrating cells known as myeloid-derived suppressor cells (MDSCs) have an immune suppressive phenotype in this microenvironment and mediate immune suppression through enzymes involved in arginine metabolism; that is, arginase- 1 and nitric oxide synthase (NOS). ${ }^{23-26}$ Filipazzi et al. recently observed an increase in MDSCs in the peripheral circulation of patients with metastatic melanoma treated with GM-CSFbased vaccine, suggesting that these cells exert immune suppression through TGF- $\beta$ production. ${ }^{27}$ In addition to the action of MDSCs, regulatory $\mathrm{T}$-lymphocytes (T-regs) infiltrate tumor sites heavily secreting TGF- $\beta$ and IL-35 and exerting active immune suppression through a contact-dependent mechanism. ${ }^{28-31}$ Tumor cells also produce immunosuppressive cytokines such as IL-10, TGF- $\beta$, and VEGF; secrete inhibitor molecule-carrying microvesicles; ${ }^{32-34}$ and express immunosuppressive proteins; for example, indoleamine 2,3-dioxy- 
genase, ${ }^{35}$ and apoptosis-inducing molecules like PD-L1, FAS-L, and TRAIL. ${ }^{36-38}$

DCs play a crucial role in the interplay between innate and adaptive responses. ${ }^{39}$ As members of the innate immune system, their main function is to present antigens to regulate the activation of the adaptive response. Therefore, DCs can provide signals of both immunostimulation and tolerance for antigenspecific T-lymphocytes, thus determining the $\mathrm{T}$ response $\left(\mathrm{Th}_{1} / \mathrm{Th}_{2}\right)$, which also depends on the activation status of the DCs at the time of Tcell priming. ${ }^{40,41}$ The microenvironment and danger signal endogens or exogens with signal transmission patterns activated by Toll-like receptors, which are found on DCs, determine the maturation status of DCs and, consequently, the type of response that will occur. The presence of self antigens without danger signals in an immunosuppressive microenvironment creates the conditions for having inactive, immature DCs, for inducing tolerance $\left(\mathrm{Th}_{2}\right)$, and for activating T-regs. ${ }^{42,43}$

\section{Immunosuppression: the role of aryl hydrocarbon receptor}

The aryl hydrocarbon receptor (AhR) is a member of the PAS protein family and is found in organisms as diverse as Drosophila melanogaster, nematodes, and mammals. ${ }^{44}$ It is a biological sensor for different stimuli, controlling neurogenesis, vascularization, circadian rhythms, metabolism, and stress responses to hypoxia, among others. ${ }^{45}$ The physiological functions of AhR during the development of an organism appear to be ancestral to its adaptive functions. The origin of dioxin-related toxicity may stem from the evolution of dioxinbinding capacity of the AhR in vertebrates. ${ }^{46,47}$ AhR-mediated changes in gene expression frequently affect cell growth and there is evidence to indicate a direct role in cell cycle control. In fact, a functional interaction has been described between AhR and retinoblastoma tumor suppressor proteins, with a consequent impact on the G1 phase of the cell cycle. ${ }^{48,49}$

Although Marshall and Kerkvliet recently reported that "a known high-affinity endogenous ligand for AhR has not been identified, thus AhR is still considered to be an orphan receptor", several low to intermediate-affinity ligands have been described; for example, low density lipoproteins, bilirubin, and plant metabolites such as proteins of the flavonoid family. ${ }^{50,51}$ Endogenous AhR ligands can be either antagonist or agonist, but the most widely studied agonist is 2,3,7,8-tetrachlorodibenzo-p-dioxin (TCDD), which also has the highest binding affinity for the receptor. ${ }^{52}$ Stevens et al. report that the " $\mathrm{EC}_{50}(\mathrm{~mol} / \mathrm{kg})=$
$10^{-12}\left(\mathrm{EC}_{50}\right.$, effective concentration required to induce a $50 \%$ effect) in mice is the dose of the ligand, sensitive to the timing of induction, which leads to $50 \%$ of the maximal cytochrome P450 gene induction". 53,54 Because its four chlorine residues prevent access to the active sites of metabolic enzymes, dioxin is metabolized poorly and causes long-term stimulation of AhR that can be detected as early as a few days after administration. ${ }^{55}$

Ligand-activated AhR has been widely studied in relation to its role in immunosuppression and several reviews provide a comprehensive summary of findings published in this area ${ }^{56} \mathrm{AhR}$ is expressed in bone marrowderived cells such as T- and B-lymphocytes, neutrophils, and macrophages, and findings generated using AhR-deficient mice indicate that the immunomodulatory effects of dioxin are AhR-mediated. ${ }^{57-59}$ Exposure to dioxin leads to profound suppression of both humoral and cellular immune responses. ${ }^{60}$ Dioxin-activated AhR suppresses T-cells, which are its primary targets, and mediates B-cell antibody response inhibition $^{61-63}$ and thymic involution, with consequent thymocyte loss, premature migration of T-cell progenitors, ${ }^{64-66}$ and overexpression of FAS-L in thymic stromal cells, resulting in Tcell apoptosis induction. ${ }^{67,68}$ Alterations in thymocytes appear transient, as adult mice exposed developmentally to dioxin do not exhibit thymic atrophy or alterations in the proportion of thymocyte subpopulations, and skewing of T-cell subpopulations is not observed in secondary lymphoid organs. ${ }^{69-71}$ Exposure of AhR to dioxin reduces the number of $\mathrm{CD}^{+}$T-cells that produce interferon alfa (IFN- $\alpha$ ) and decreases the level of IFN- $\gamma$ produced by cells in lymph nodes, providing yet another indicator of suppressed $\mathrm{CD} 8^{+} \mathrm{T}$-cell )

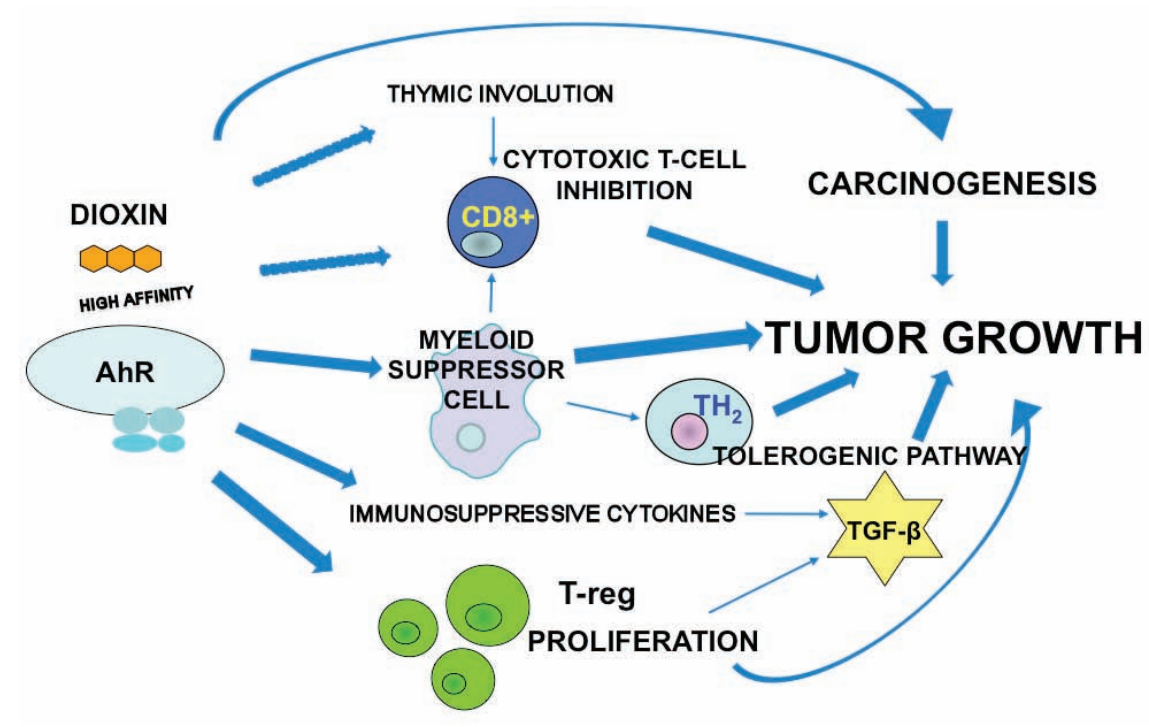

Figure 1. Immunosuppressive action of dioxin-AhR binding. differentiation. ${ }^{54,55}$ phenotype, function, and number in different model systems, suggesting that decreased DC function or number could be responsible for suppression of $\mathrm{CD}^{+}$T-cell response. ${ }^{72,73}$ Exposure to dioxin induces expression of sevMHC-II antigens, CD40, and CD24, and further production of IL-12 by DC, with a consequently higher T-cell proliferative response, in mice. However, exposure to dioxin-AhR significantly reduces the number of DCs in the spleen of treated mice within a week, and some authors have postulated that this decline reflects enhanced apoptosis following the inappropriate activation of these cells. ${ }^{74}$ Premature loss of DCs in dioxin-treated mice may result in insufficient contact time with T-cells to sustain their full activation and differentiation. ${ }^{75}$ While dioxin exposure inhibits the activation of DCs previously treated with tumor necrosis factor (TNF- $\alpha$ ) or anti-CD40, leading to inefficient DC maturation, it also enhances FAS-mediated apoptosis in effector cells through the regulation of FAS and FAS-L promoter. ${ }^{76-78}$ Two important issues in dioxin-AhR-induced immunosuppression that have recently come to the fore are its direct influence on the expansion of regulatory T-cells $\mathrm{CD}^{+} \mathrm{CD}^{2} 5^{+} \mathrm{F} \mathrm{xP} 3^{+}$(T-regs) and its adverse effect on $\mathrm{CD}^{+}$T-cell response. ${ }^{79,80}$ AhR activation by several different ligands has been reported to have an impact on the differentiation and development of both T-regs and IL-17-producing T-helper cells (Th17 cells) ${ }^{81-83}$ The immunosuppressive action of dioxin-AhR binding is shown in Figure 1.

It was reported recently that the EpsteinBarr virus (EBV)-encoded nuclear protein
The AhR-dioxin ligand has an impact on DC eral accessory molecules on DCs including 
EBNA-3 interacts with AhR and XAP-2 ${ }^{84,85}$ This is an intriguing discovery because EBNA-3 plays a role in the transformation of infected B-cells and, although the underlying mechanism is not known, dioxin exposure is a risk factor in the development of non-Hodgkin lymphoma and other forms of cancer. ${ }^{86,87}$ EBNA3 may influence AhR-regulated genes by enhancing the transcriptionally-active form of AhR and helping to retain AhR in the nucleus. The studies carried out seem to indicate a merging or synergy between AhR- and EBVregulated mechanisms that controls cellular function. In addition to suggesting that AhR may interact with viral proteins in interesting ways, these observations may also partially explain the relationship between AhR-dioxin activation and some forms of cancer. ${ }^{88,89}$

Furthermore, functional defects in the immune response to the influenza virus infection have been reported after exposure to AhR agonists in childhood.9,91 Increased dioxin levels in breast milk and cord blood correlate with increased incidence of otitis media, respiratory tract infections in infants, and reduced antibody responses to childhood vaccinations. ${ }^{92-95}$ The consequences of developmental exposure to dioxin may persist into adulthood, with alterations in leukocyte function, as seen in mice models. ${ }^{96,97}$

Finally, in addition to its powerful immunosuppression, the ligand status of $A h R$ is capable of modulating activation of the BRCA1 promoter by estrogen. BRCA-1 expression is downregulated in the absence of mutations in the BRCA-1 gene, suggesting that disruption of BRCA-1 expression by dioxin-AhR may contribute to the onset of breast cancer. ${ }^{98}$

\section{Dioxin: 2,3,7,8-tetra- chlorodibenzo-p-dioxin}

Dioxins are organochlorine compounds and dioxin itself is listed as an IARC class I carcinogen. ${ }^{99,100}$ Present in nature only in volcanic emissions or forest fires, these compounds have been released from industrial and waste incinerators over the last few decades, causing widespread contamination of food and significant toxic body burdens in nearly all living organisms. ${ }^{101}$ An assessment of dioxins by the European Dioxin Inventory in 2005 found that the biggest single source of dioxins between 2000 and 2005 in the United Kingdom was industrial incineration and, in particular, that of urban waste, producing $38 \%$ of the total amount, and 20 -fold that of road transport ${ }^{102}$ (Figure 2).

Dioxin molecules are extremely stable and spread rapidly through the environment, especially via the soil and water, inevitably polluting the food chain and accumulating in fatty

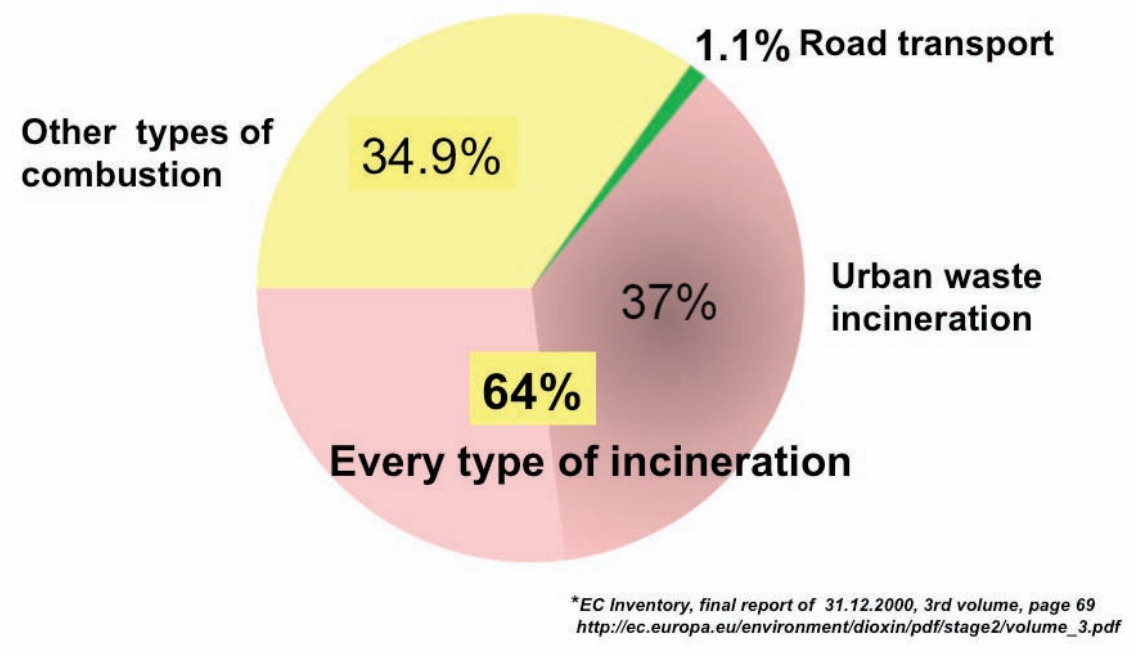

Figure 2. Official European documents* showing data for Italy: $295.5 \mathrm{gr} /$ year of dioxin (toxic equivalent factor - TEQ) by incineration plants (64\% of the total). Of these, 170.6 gr/year (37\% of the total) are produced by urban waste incineration plants alone.

\section{THE THREE ‘E'S OF TUMOR IMMUNOEDITING}

G.P. DUNN; Nat. Immunol. 2002 and Immunity 2004

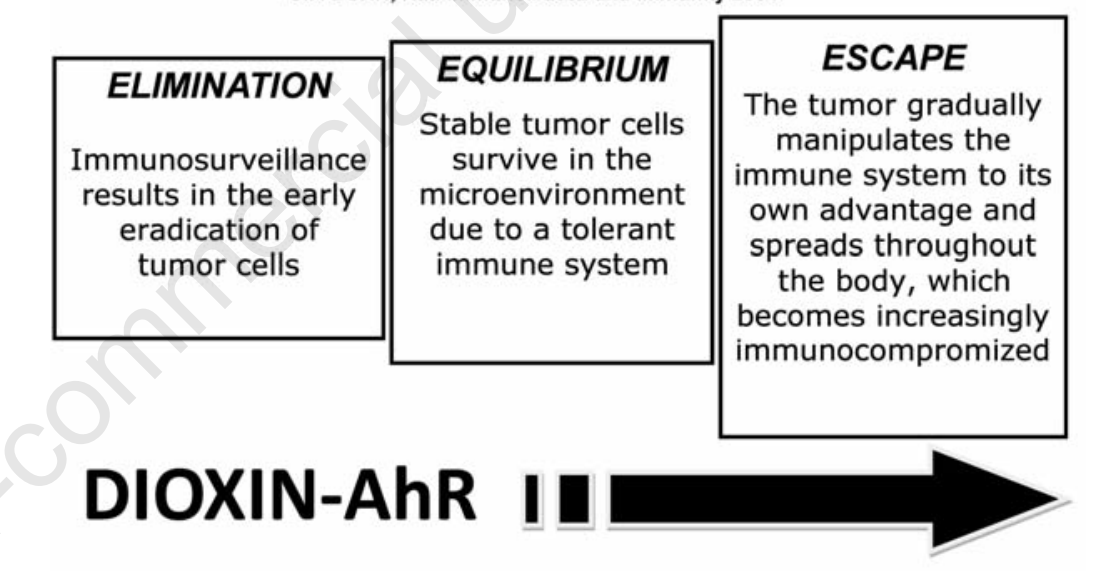

Figure 3. Dioxin-AhR binding acts at all levels by encouraging the shift toward tumor immunosuppression.

tissues and milk as a result of their lipsolubility. ${ }^{103}$ The U.S. Environmental Protection Agency's current estimate of dioxin's carcinogenicity derived from animal studies states that the average person's exposure to dioxin, which is 3-6 pg/kg/day, gives a lifetime cancer risk of between 500 and 1000/1,000,000..$^{104,105}$ This is in stark contrast to what has been established as an acceptable cancer risk; that is, between $1 / 100,000$ and $1 / 1,000,000$. Although tolerable daily intake (TDI) is set at 2 $\mathrm{pg} / \mathrm{kg} /$ day in Europe, it must be remembered that dioxins have a half-life in humans of 7-10 years, suggesting that this "limit" does not safeguard against a potential accumulation within the body. Thus, although it follows that the regular eating of foods considered legally "safe" could result in the building up of high quantities of dioxin over the years, we need to verify whether the molecules deposited and accumulated in fatty tissue are all available to bind with the receptor. ${ }^{45}$

\section{Discussion and Conclusions}

Even though overall cancer mortality rates have remained unchanged for decades, incidence in malignant tumor types unrelated to 
cigarette smoking is increasing and there is strong scientific evidence to suggest that the risk of developing cancer can be significantly reduced by avoiding exposure to environmental carcinogens. ${ }^{106-108}$ However, despite the enormous financial resources utilized, oncologists, researchers, and public health authorities, rather than concentrating on preventing cancer, have focused on treating it once it strikes. ${ }^{109}$ While chemotherapeutic drugs are showing their limits now, target therapies still have to demonstrate their real efficacy, and immunological therapies, which aroused great interest in the 1980s, now are having to deal with the numerous facets of tumor immunosuppression. The relationship between cancer and the immune system is highly complex and subject to numerous internal cross-checks, making it very difficult to understand and manipulate. As hypothesized by the cancer immunoediting concept, the immunosurveillance phase and perhaps also that of equilibrium should, in theory, protect us from tumor growth. Over the years, however, they seem to have become less and less effective if we consider the continuous increase in cancer incidence, especially in young people. ${ }^{110}$ There is evidence now to show that an external substance like dioxin, virtually non-existent two hundred years ago and indiscriminately released into the environment by man, may be responsible for causing an important dysregulation of our immune system, in addition to its being classed officially as a powerful carcinogen. ${ }^{44,45,54}$ Although most of the data reported in our paper are based on research carried out on animals and now need to be verified in humans, it has become clear that the activation of AhR by dioxin may create a perverse alliance promoting the onset, growth, and spread of cancer. ${ }^{111}$

Dioxin released into the environment, especially from waste incinerators, has a very high affinity with its receptor AhR and, given the long elimination half-life of the compound in humans, causes long-term effects (e.g. cell cycle alteration, functional interaction with retinoblastoma suppressor proteins), which are known to include severe immune suppression. ${ }^{47,48,112,113}$ Returning to the concept of immunoediting, it is thought that the strong and lasting stimulation of AhR is capable of speeding up the shift from one immunoediting phase to the next, rendering elimination ineffective, destabilizing equilibrium, and creating a long-lasting condition of tumor escape (Figure 3).

Such a phenomenon, becoming stronger and more lethal as time passes and more dioxin accumulates, has led to growing concern for young people, whose entire existence has probably been conditioned by this process. In addition to premature degeneration of the thymus caused by the action of activated AhR in the earliest stages of life ${ }^{69-71}$ there is further preclinical evidence to support this concern, such as an affinity with Epstein-Barr virus in determining Hodgkin's lymphoma ${ }^{84.87}$ and modulation of the BRCA-1 gene for breast cancer..$^{98}$ The $2 \%$ annual increase in the incidence of childhood tumors registered over the last 10 years in Italy, the increase in leukemias, lymphomas, and sarcomas in young people/adults, and the $1 \%$ increase in the incidence of breast cancers in the age group $<45$ years (1998-2005) may be related to the abovementioned mechanisms. ${ }^{11,114,115}$ Furthermore, recent reports in the literature indicate that in critically polluted areas, human breast milk contains very high levels of dioxin. ${ }^{116,117}$ There are also growing fears that the activity of AhR on the fetus may create a predisposition to immunosuppression starting in the mother's womb, if not already established in the gonadal cells of the parents, creating transgenerational cancerogenesis. ${ }^{118-123}$

In conclusion, although our immune system seems to be capable of protecting us from the onset, growth, and spread of tumors, it finds an insuperable cancer ally in a microenvironment altered by immunosuppression elements. It is clear that a change in strategy in the war against cancer is needed. We cannot set aside antineoplastic therapies, early diagnosis, or screening practices, nor can we continue to ignore that primary prevention must become our main objective. ${ }^{.24,125}$ We are morally obliged to investigate a missing link in the cancer puzzle that demonstrates the direct involvement of environmental pollution in determining serious degenerative diseases. Although it is possible that such transformation occurs in the early stages of life or even before we are born, it will be future generations who face the consequences. ${ }^{126}$ The time has come not only to reduce and eliminate the sources of toxic emissions that are responsible for such damage, but also to carry out research into verifying the hypothesis of immune system impairment and to identify potential solutions. ${ }^{127}$

\section{References}

1. Ichim CV. Revisiting immunosurveillance and immunostimulation: implications for cancer immunotherapy. J Transl Med 2005; $3: 8$.

2. Topalian SL, Rosenberg SA. Tumor specific cytolysis by lymphocytes infiltrating human melanomas. J Immunol 1989;142: 3714-25.

3. Boon T, Cerottini JC, van den Eynde B, et al. Tumor antigens recognized by T lymphocytes. Ann Rev Immunol 1994;12:337-65.

4. Pardoll D. Does the immune system see tumors as foreign or self? Annu Rev
Immunol 2003;21:807-39.

5. Ferrone S, Whiteside TL. Tumor microenvironment and immune escape. Surg Oncol Clin N Am 2007;16:755-74, viii.

6. Whiteside TL. The tumor microenvironment and its role in promoting tumor growth. Oncogene 2008;27:5904-12.

7. Dunn GP, Bruce AT, Ikeda H, et al. Cancer immunoediting: from immunosurveillance to tumor escape. Nat Immunol 2002;3:9918.

8. Dunn GP, Old LJ, Schreiber RD. The immunobiology of cancer immunosurveillance and immunoediting. Immunit 2004;21:137-48.

9. Swann JB, Smyth MJ. Immune surveillance of tumors. J Clin Invest 2007;117: 1137-46.

10. Koebel CM, Vermi W, Swann JB, et al. Adaptive immunity maintains occult cancer in an equilibrium state. Nature 2007; 450:903-7.

11. Marincola FM, Jaffee EM, Hicklin JD, et al. Escape of human solid tumors from T-cell recognition: molecular mechanisms and functional significance. Adv Immunol 2000;74:181-273.

12. Campoli M, Ferrone S, Zea AH, et al. Mechanisms of tumor evasion. Cancer Treat Res 2005;123:61-88.

13. Drake CG, Jaffee E, Pardoll DM. Mechanisms of immune evasion by tumors. Adv Immunol 2006;90:51-81.

14. Nagorsen D, Scheibenbogen C, Marincola FM, et al. Natural T cell immunity against cancer. Clin Cancer Res 2003;9:4296-303.

15. Foss FM. Immunologic mechanisms of antitumor activity. Semin Oncol 2002;29: S5-11.

16. Wang T, Niu G, Kortylewski M, et al. Regulation of the innate and adaptive immune responses by Stat- 3 signaling in tumor cells. Nat Med 2004:10:48-54.

17. Rossi M, Young JW. Human dendritic cells: potent antigen-presenting cells at the crossroads of innate and adaptive immunity. J Immunol 2005;175:1373-81.

18. Mocellin S, Wang E, Marincola FM. Cytokines and immune response in the tumor microenvironment. J Immunother 2001;24:392-407.

19. Dougan M, Dranoff G. Inciting inflammation: the RAGE about tumor promotion. $\mathrm{J}$ Exp Med 2008;205:267-70.

20. Davidson-Moncada J, Papavasiliou FN, Tam W. MicroRNAs of the immune system. Roles in inflammation and cancer. Ann NY Acad Sci 2010;1183:183-94.

21. Maldonado-Lopez R, Moser M. Dendritic cell subsets and regulation of Th1/Th2 responses. Semin Immunol 2001;13:27582.

22. Khong HT, Restifo NP. Natural selection of tumor variants in the generation of "tumor 
escape" phenotypes. Nat Immunol 2002;3:999-1005.

23. Muller AJ, Melachowski WP, Prendergast GC. Indoleamine 2,3-dioxygenase in cancer: targeting pathological immune tolerance with small-molecule inhibitors. Expert Opin Ther Targets 2005;9:831-49.

24. Serafini P, Borrello I, Bronte V. Myeloid suppressor cells in cancer: recruitment, phenotype, properties, and mechanisms of immune suppression. Semin Cancer Biol 2006;16:53-65.

25. Ochoa AC, Zea AH, Hernandez C, et al. Arginase, prostaglandins, and myeloidderived suppressor cells in renal cell carcinoma. Clin Cancer Res 2007;13:721-6s.

26. Sica A, Bronte V. Altered macrophage differentiation and immune dysfunction in tumor development. J Clin Invest 2007; 117:1155-66.

27. Filipazzi P, Valenti R, Huber V, et al. Identification of a new subset of myeloid suppressor cells in peripheral blood of melanoma patients with modulation by a granulocyte-macrophage colony-stimulation factor-based antitumor vaccine. J Clin Oncol 2007;25:2546-53.

28. Levings MK, Sangregorio R, Sartirana C, et al. Human CD25+CD4+ T suppressor cell clones produce transforming growth factor beta, but not interleukin 10, and are distinct from type $1 \mathrm{~T}$ regulatory cells. J Exp Med 2002;196:1335-46.

29. Terabe M, Berzofsky JA. Immunoregulatory T cells in tumor immunity. Curr Opin Immunol 2004;16:157-62.

30. Collison LW, Workman CJ, Kuo TT, et al. The inhibitory cytokine IL-35 contributes to regulatory T-cell function. Nature 2007;450:566-9.

31. Curiel TJ. Tregs and rethinking cancer immunotherapy. J Clin Invest 2007;117: 1167-74.

32. Andreola G, Rivoltini L, Castelli C, et al. Induction of lymphocyte apoptosis by tumor cell secretion of FasL-bearing microvesicles. J Exp Med 2002;195:130316.

33. Martinez-Lorenzo MJ, Anel A, Alava MA, et al. The human melanoma cell line MelJuSo secretes bioactive FasL and AP02L/TRAIL on the surface of microvesicles. Possible contribution to tumor counterattack. Exp Cell Res 2004;295:315-29.

34. Whiteside TL. Tricks tumors use to escape from immune control. Oral Oncol 2009; 45:119-23.

35. Munn DH, Mellor AL. Indoleamine 2,3dioxygenase and tumor-induced tolerance. J Clin Invest 2007;117:1147-54.

36. Whiteside TL, Rabinowich $\mathrm{H}$. The role of Fas/FasL in immuno-suppression induced by human tumors. Cancer Immunol Immunother 1998;46:175-84.
37. Bron LP, Scolyer RA, Thompson JF, et al. Histological expression of tumour necrosis factor-related apoptosis-inducing ligand (TRAIL) in human primary melanoma. Pathology 2004;36:561-5.

38. Butte MJ, Peña-Cruz V, Kim MJ, et al. Interaction of human PD-L1 and B7-1. Mol Immunol 2008;45:3567-72.

39. Banchereau J, Steinman RM. Dendritic cells and the control of immunity. Nature 1998;392:245-52.

40. Shurin MR. Dendritic cells presenting tumor antigen. Cancer Immunol Immunother 1996;43:158-64.

41. Lanzavecchia A, Sallusto F. Regulation of T cell immunity by dendritic cells. Cell 2001;106:263-6.

42. Mellman I, Steinman RM. Dendritic cells: specialized and regulated antigen processing machines. Cell 2001;106:255-8.

43. Munn DH. Tolerogenic antigen-presenting cells. Ann NY Acad Sci 2002;961:343-5.

44. Esser C, Rannug A, Stockinger B. The aryl hydrocarbon receptor in immunity. Trends Immunol 2009;30:447-54.

45. Schecter A, Birnbaum L, Ryan JJ, et al. Dioxins: an overview. Environ Res 2006; 101:419-28.

46. Hahn ME. The aryl hydrocarbon receptor: a comparative perspective. Comp Biochem Physiol C Pharmacol Toxicol Endocrinol 1998;121:23-53.

47. Hahn ME. Aryl hydrocarbon receptors: diversity and evolution. Chem Biol Interact 2002;141:131-60.

48. Elferink CJ. Aryl hydrocarbon receptormediated cell cycle control. Prog Cell Cycle Res 2003;5:261-7.

49. Marlowe JL, Puga A. Aryl hydrocarbon receptor, cell cycle regulation, toxicity, and tumorigenesis. J Cell Biochem 2005;96: 1174-84.

50. Marshall NB, Kerkvliet NI. Dioxin and immune regulation. Emerging role of aryl hydrocarbon receptor in the generation of regulatory T cells. Ann NY Acad Sci 2010; 1183:25-37.

51. Stockinger B, Veldhoen M, Hirota K. Modulation of Th17 development and function by activation of the aryl hydrocarbon receptor--the role of endogenous ligands. Eur J Immunol 2009;39:652-4.

52. Mimura J, Fujii-Kuriyama Y. Functional role of AhR in the expression of toxic effects by TCDD. Biochim Biophys Acta 2003;1619:263-8.

53. Bohonowych JE, Denison MS. Persistent binding of ligands to the aryl hydrocarbon receptor. Toxicol Sci 2007;98:99-109.

54. Stevens EA, Mezrich JD, Bradfield CA. The aryl hydrocarbon receptor: a perspective on potential roles in the immune system. Immunology 2009;127:299-311.

55. Kerkvliet NI. Recent advances in under- standing the mechanisms of TCDD immunotoxicity. Int Immunopharmacol 2002;2:277-91.

56. Lawrence BP, Kerkvliet NI. Immune modulation by TCDD and related polyhalogenated aromatic hydrocarbons. In: Immunotoxicology and immunopharmacology. Luebke R, House R, Kimber I, eds. Boca Raton (FL): CRC Press; 2006, pp 239-58.

57. Vorderstrasse BA, Steppan LB, Silverstone $\mathrm{AE}$, et al. Aryl hydrocarbon receptor-deficient mice generate normal immune responses to model antigens and are resistant to TCDD-induced immune suppression. Toxicol Appl Pharmacol 2001; 171:157-64.

58. Lawrence BP, Roberts AD, Neumiller JJ, et al. Aryl hydrocarbon receptor activation impairs the priming but not the recall of influenza virus-specific CD8+ T cells in the lung. J Immunol 2005;177:5819-28.

59. Teske S, Bohn AA, Regal JF, et al. Exploring mechanisms that underlie aryl hydrocarbon receptor-mediated increases in pulmonary neutrophilia and diminished host resistance to influenza A virus. Am J Physiol Lung Cell Mol Physiol 2005;289: 111-24.

60. Kerkvliet NI. Immunological effects of chlorinated dibenzo-p-dioxins. Environ Health Perspect 1995;103:S47-53.

61. Kerkvliet NI, Baecher-Steppan L, Shepherd DM, et al. Inhibition of TC-1 cytokine production, effector cytotoxic T lymphocyte development and alloantibody production by 2,3,7,8-tetrachlorodibenzo-p-dioxin. J Immunol 1996;157:2310-9.

62. Ito $\mathrm{T}$, Inouye $\mathrm{K}$, Fujimaki $\mathrm{H}$, et al. Mechanism of TCDD-induced suppression of antibody production: effect on $\mathrm{T}$ cellderived cytokine production in the primary immune reaction of mice. Toxicol Sci 2002;70:46-54.

63. Allan LL, Sherr DH. Constitutive activation and environmental chemical induction of the aryl hydrocarbon receptor/transcription factor in activated human B lymphocytes. Mol Pharmacol 2005;67:1740-50.

64. Laiosa MD, Wyman A, Murante FG, et al. Cell proliferation arrest within intrathymic lymphocyte progenitor cells causes thymic atrophy mediated by the aryl hydrocarbon receptor. J Immunol 2003;171: 4582-91.

65. Temchura VV, Frericks M, Nacken W, et al. Role of the aryl hydrocarbon receptor in thymocyte emigration in vivo. Eur $\mathrm{J}$ Immunol 2005;35:2738-47.

66. McMillan BJ, McMillan SN, Glover E, et al. 2,3,7,8-tetrachlorodibenzo-p-dioxin induces premature activation of the KLF2 regulon during thymocyte development. J Biol Chem 2007;282:12590-7.

67. Fisher MT, Nagarkatti M, Nagarkatti PS. 
Combined screening of thymocytes using apoptosis-specific cDNA array and promoter analysis yields novel gene targets mediating TCDD-induced toxicity. Toxicol Sci 2004;78:116-24.

68. Camacho I, Singh N, Hegde V, et al. Treatment of mice with 2,3,7,8-tetrachlorodibenzo-p-dioxin leads to aryl hydrocarbon receptor-dependent nuclear translocation of NF-kappa B and expression of fas ligand in thymic stromal cells and consequent $\mathrm{T}$ cell apoptosis. $\mathrm{J}$ Immunol 2005;175:90-103.

69. Fine J, Gasiewicz T, Silverstone A. Lymphocyte stem cell alterations following perinatal exposure to 2,3,7,8-tetrachlorodibenzo-p-dioxin. Mol Pharmacol 1989;35:18-25.

70. Nohara K, Jujimaki H, Tsukumo S, et al. The effects of perinatal exposure to low doses of 2,3,7,8-tetrachlorodibenzo-p-dioxin on immune organs in rats. Toxicology 2000;154:123-33.

71. Vorderstrasse BA, Cundiff J, Lawrence BP. Developmental exposure to the potent aryl hydrocarbon receptor agonist 2,3,7,8-tetrachlorodibenzo-p-dioxin impairs the cellmediated immune response to infection with influenza A virus, but enhances elements of innate immunity. J Immunotoxicol 2004;1:103-12.

72. Vorderstrasse BA, Dearstyne EA, Kerkvliet NI. Influence of 2,3,7,8-tetrachlorodibenzo-p-dioxin on the antigen-presenting activity of dendritic cells. Toxicol Sci 2003; 72:103-12.

73. Laupeze B, Amiot L, Sparfel L, et al. Polycyclic aromatic hydrocarbons affect functional differentiation and maturation of human monocyte-derived dendritic cells. J Immunol 2002;168:2652-8.

74. Ruby CE, Funatake CJ, Kerkvliet NI. 2,3,7,8 tetrachlorodibenzo-p-dioxin (TCDD) directly enhances the maturation and apoptosis of dendritic cells in vitro. $\mathrm{J}$ Immunotoxicol 2005;1:159-66.

75. Vorderstrasse BA, Kerkvliet NI. 2,3,7,8tetrachlorodibenzo-p-dioxin affects the number and function of murine splenic dendritic cells and their expression of accessory molecules. Toxicol Appl Pharmacol 2001;171:117-25.

76. Ruby CE, Leid M, Kerkvliet NI. 2,3,7,8tetrachlorodibenzo-p-dioxin suppresses tumor necrosis factor-alpha and antiCD40-induced activation of NF-kappaB/Rel in dendritic cells: p50 homodimer activation is not affected. Mol Pharmacol 2002;62:722-8.

77. Lee JA, Hwang JA, Sung HN, et al. 2,3,7,8tetrachlorodibenzo-p-dioxin modulates functional differentiation of mouse bone marrow-derived dendritic cells: downregulation of RelB by 2,3,7,8-tetrachlorodiben- zo-p-dioxin. Toxicol Lett 2007;173:31-40.

78. Singh NP, Nagarkatti M, Nagarkatti PS. Role of dioxin response element and nuclear factor-kappa B motifs in 2,3,7,8tetrachlorodibenzo-p-dioxin-mediated regulation of Fas and Fas ligand expression. Mol Pharmacol 2007;71:145-57.

79. Quintana FJ, Basso AS, Iglesias AH, et al. Control of T(reg) and T(H)17 cell differentiation by the aryl hydrocarbon receptor. Nature 2008;453:65-71.

80. Haeryfar SM, DiPaolo RJ, Tscharke DC, et al. Regulatory T cells suppress CD8+ T cell responses induced by direct priming and cross-priming and moderate immunodominance disparities. J Immunol 2005;174: 3344-51.

81. Funatake CJ, Marshall NB, Steppan LB, et al. Cutting edge: activation of the aryl hydrocarbon receptor by 2,3,7,8-tetrachlorodibenzo-p-dioxin generates a population of CD4+ CD25+ cells with characteristics of regulatory $\mathrm{T}$ cells. $\mathrm{J}$ Immunol 2005;175:4184-8.

82. Kimura A, Naka T, Nohara K, et al. Aryl hydrocarbon receptor regulates Statl activation and participates in the development of Th17 cells. Proc Natl Acad Sci USA 2008; 105:9721-6.

83. Veldhoen M, Hirota K, Westendorf AM, et al. The aryl hydrocarbon receptor links TH17-cell-mediated autoimmunity to environmental toxins. Nature 2008;453: 106-9.

84. Kashuba E, Kashuba V, Pokrovskaja K, et al. Epstein-Barr virus encoded nuclear protein EBNA-3 binds XAP-2, a protein associated with Hepatitis B virus $\mathrm{X}$ antigen. Oncogene 2000;19:1801-6.

85. Kashuba EV, Gradin K, Isaguliants M, et al. Regulation of transactivation function of the aryl hydrocarbon receptor by the Epstein-Barr virus-encoded EBNA-3 protein. J Biol Chem 2006;281:1215-23.

86. Hardell L, Lindström G, van Bavel B, et al. Adipose tissue concentrations of dioxins and dibenzofurans, titers of antibodies to Epstein-Barr virus early antigen and the risk for non-Hodgkin lymphoma. Environ Res 2001;87:99-107.

87. Küppers R. B cells under influence: transformation of B cells by Epstein-Barr virus. Nat Rev Immunol 2003;3:801-12.

88. Stancek D, Kosecká G, Oltman M, et al. Links between prolonged exposure to xenobiotics, increased incidence of hepatopathies, immunological disturb ances and exacerbation of latent EpsteinBarr virus infections. Int $\mathrm{J}$ Immuno pharmacol 1995;17:321-8.

89. Beischlag TV, Luis Morales J, Hollingshead $\mathrm{BD}$, et al. The aryl hydrocarbon receptor complex and the control of gene expression. Crit Rev Eukaryot Gene Expr
2008;18:207-50.

90. Vorderstrasse BA, Cundiff J, Lawrence BP. A dose-response study of the effects of prenatal and lactational exposure to TCDD on the immune response to influenza A virus. J Toxicol Environ Health 2006;69:1-19.

91. Stockinger B. Beyond toxicity: aryl hydrocarbon receptor-mediated functions in the immune system. J Biol 2009;8:61.

92. Dewailly E, Ayotte P, Bruneau S, et al. Susceptibility to infections and immune status in Inuit infants exposed to organochlorines. Environ Health Perspect 2000;108:205-11.

93. ten Tusscher GN, Steerenberg PA, Van Loveren $\mathrm{H}$, et al. Persistent hematologic and immunologic disturbances in 8-yearold Dutch children associated with perinatal dioxin exposure. Environ Health Perspect 2003;111:1519-23.

94. Dallaire F, Dewailly E, Muckle G, et al. Acute infections and environmental exposure to organochlorines in Inuit infants from Nunavik. Environ Health Perspect 2004;112:1359-65.

95. Heilmann C, Grandjean P, Welhe P, et al. Reduced antibody responses to vaccinations in children exposed to polychlorinated biphenyls. PLOS Med 2006;3:e311.

96. Gehrs B, Samialowicz R. Persistent suppression of delayed-type hypersensitivity in adult F344 rats after perinatal exposure to 2,3,7,8-tetrachlorodibenzo-p-dioxin. Toxicology 1999;134:79-88.

97. Walker DB, Williams WC, Copeland CB, et al. Persistent suppression of contact hypersensitivity and altered T cell parameters in F344 rats exposed perinatally to 2,3,7,8-tetrachlorodibenzo-p-dioxin (TCDD). Toxicology 2004;197:57-66.

98. Hockings JK, Thorne PA, Kemp MQ, et al. The ligand status of the aromatic hydrocarbon receptor modulates transcriptional activation of BRCA-1 promoter by estrogen. Cancer Res 2006;66:2224-32.

99. Tomatis L. The IARC monographs program: changing attitudes towards public health. Int J Occup Environ Health 2002; 8:144-52.

100.Steenland K, Bertazzi P, Baccarelli A, et al. Dioxin revisited: developments since the 1997 IARC classification of dioxin as a human carcinogen. Environ Health Perspect 2005;112:1265-8.

101.Danaei G, Vander Hoorn S, Lopez AD, et al. Comparative Risk Assessment collaborating group (Cancers). Causes of cancer in the world: comparative risk assessment of nine behavioural and environmental risk factors. Lancet 2003;366:1784-93.

102.Thompson J, Anthony H. The Health Effects of Waste Incinerators. 4th Report of the British Society for Ecological Medicine. 2nd edn, June 2008. 
http://www.ecomed.org.uk/content/Inciner atorReport_v3.pdf

103.Schecter A, Gasiewicz T. Health hazard assessment of chlorinated dioxins and dibenzofurans contained in human milk. Chemosphere 1987;16:2147-54.

104.Schecter A, Startin J, Wright C, et al. Congener-specific levels of dioxins and dibenzofurans in US food and estimated daily dioxin toxic equivalent intake. Env Health Perspect 1994;102:962-6.

105.US Environmental Protection Agency. Health Assessment Document for 2,3,7,8 tetrachlorodibenzo-p-dioxin and Related Compounds. Vol 1-3, Review Draft. Washington DC: US EPA Office of Research and Development (EPA/600/BP92-001), 1994.

106.Belpomme D, Irigaray P, Sasco AJ, et al. The growing incidence of cancer: role of lifestyle and screening dectection. Int $\mathbf{J}$ Oncol 2007;30:1037-49.

107.Irigaray I, Newby JA, Clapp R, et al. Lifestyle-related factors and environmental agents causing cancer: an overview. Biomed Pharmacother 2007;61:640-58.

108.Clapp RW, Jacobs MM, Loechler EL. Environmental and occupational causes of cancer: new evidence 2005-2007. Rev Environ Health 2008;23:1-37.

109.Epstein SS. Cancer-Gate: How to win the losing cancer war. Amityville, NY: Baywood Publishing Company, Inc, 2005.
110.AIRTUM Working Group. Tumori infantili. Incidenza, sopravvivenza, andamenti temporali. Epidemiol Prev 2008;32:S1-112.

111.AIRTUM Working Group. New incidence mortality data 2003-2205. Epidemiol Prev 2009;33:S.

112.Puga A, Ma C, Marlowe JL. The aryl hydrocarbon receptor cross-talks with multiple signal transduction pathways. Biochem Pharmacol 2009;77:713-22.

113. Ma C, Marlowe JL, Puga A. The aryl hydrocarbon receptor at the crossroads of multiple signaling pathways. EXS 2009;99:23157.

114.Porta D, Milani S, Lazzarino AI, et al. Systematic review of epidemiological studies on health effects associated with management of solid waste. Environ Health 2009;8:60.

115.Irigaray P, Belpomme D. Basic properties and molecular mechanisms of exogenous chemical carcinogens. Carcinogenesis 2010;31:135-48.

116.Wittsiepe J, Fürst P, Schrey P, et al. PCDD/F and dioxin-like PCB in human blood and milk from German mothers. Chemosphere 2007;67:286-94.

117.Li J, Zhang L, Wu Y, et al. A national survey of polychlorinated dioxins, furans (PCDD/Fs) and dioxin-like polychlorinated biphenyls (dl-PCBs) in human milk in China. Chemosphere 2009;75:1236-42.

118.Tomatis L, Narod S, Yamasaki H. Trans- generation transmission of carcinogenic risk. Carcinogenesis 1992;13:145-51.

119.Knox EG. Roads, railways, and childhood cancers. J Epidemiol Community Health 2006;60:136-41.

120.Pacchierotti F, Ranaldi R, EichenlaubRitter U, et al. Evaluation of aneugenic effects of bisphenol A in somatic and germ cells of the mouse. Mutat Res 2008;651:6470 .

121.Robaire B. Is it my grandparents' fault? Nat Med 2008;14:1186-7.

122.Soto AM, Vandenberg LN, Maffini MV, et al. Does breast cancer start in the womb? Basic Clin Pharmacol Toxicol 2008;102; 125-33.

123.Jedrychowski W, Perera F, Mrozek-Budzyn D, et al. Gender differences in fetal growth of newborns exposed prenatally to airborne fine particulate matter. Environ Res 2009;109:447-56.

124.Millstone E, Brunner E, White I. Plagiarism or protecting public health? Nature 1994;371:647-8.

125.Tomatis L, Huff J. Evolution of cancer etiology and primary prevention. Environ Health Perspect 2001;109:A458-60.

126.Sonnenschein C, Soto AM. Theories of carcinogenesis: an emerging perspective. Semin Cancer Biol 2008;18:372-7.

127.Epstein SS. The politics of cancer. JAMA 2000;284:442. 